\title{
ANALISIS PENEGAKAN HUKUM TERHADAP PELAKU TINDAK PIDANA PENYEROBOTAN TANAH YANG TERJADI DI WILAYAH HUKUM POLDA SULAWESI SELATAN
}

\section{Analysis of Law Enforcement Against Perpetrators of Criminal Actions of a Land Grab Occuring in the Jurisdiction of South Sulawesi Regional Police}

\author{
Ferdy $^{1}$, Marwan Mas ${ }^{2}$, Abdul Salam Siku ${ }^{2}$ \\ ${ }^{1}$ Kepolisian Daerah Sulawesi Selatan \\ ${ }^{2}$ Program Studi Ilmu Hukum Program Pascasarjana Universitas Bosowa \\ Email: ferdy@gmail.com
}

Diterima: 01 Agustus 2020/Disetujui: 05 Desember 2020

\begin{abstract}
ABSTRAK
Tujuan yang ingin dicapai dalam penelitian ini adalah; (1) Untuk mengetahui dan menganalisis upaya kepolisian dalam menanggulangi tindak pidana Kekerasan Dalam RumahTangga di wilayahhukumPolsekMandai. (2) Untuk mengetahui dan menganalisis Hambatan-hambatan yang dihadapi penyidik kepolisian dalam upaya menanggulangi tindak pidana Kekerasan Dalam RumahTangga di wilayah hokum Polsek Mandai. Penelitian yang digunakan adalah penelitian hukum empiris yaitu suatu metode penelitian hukum yang berfungsi untuk melihat hukum dalam artian nyata dan meneliti bagaimana bekerjanya hukum di lingkungan masyarakat. Penelitian dilakukan di wilayah hukum Polsek Mandai Polres Maros, dan yang menjadi fokus pada peneilitian ini ada dua yakni: Preventif dan Represif. Hasil penelitian menujukkan bahwa upaya penanggulangan dilakukan secara preventif dan represif. Sementara kendala yang dihadapi dalam perlindungan perempuan korban kekerasan dalam rumah tangga adalah tidak adanya peraturan pelaksana terkait perintah perlindungan, keterbatasan dana dan keluarnya hasil visum et repertum membutuhkan waktu yang lama, keterbatasan sumber daya manusia seperti tidak adanya tenaga psikolog, kurang maksimalnya pelayanan konseling untuk korban, dan kurangnya pemahaman polisi terhadap pentingnya perintah perlindungan bagikorban. Keempat, keterbatasan sarana prasarana dan terdapat korban yangenggan ditempatkan di rumah aman
\end{abstract}

Kata Kunci : Penegakan Hukum, Penyerobotan,Tanah, Polda, Sulawesi Selatan

\begin{abstract}
The objectives of this research are; (1) to find out and to analyze the efforts of the police in overcoming criminal acts of Domestic Violence in the jurisdiction of the Mandai Police. (2) To find out and analyze the obstacles faced by police investigators in efforts to overcome criminal acts of domestic violence in the jurisdiction of the Mandai Police. The research used is empirical legal research, which is a legal research method that functions to see the law in a real sense and to examine how the law works in society. The research was carried out in the jurisdiction of the Mandai Police in Maros, and the focus of this research are: Preventive and Repressive. The results of this study show that prevention efforts are carried out in a preventive and repressive manner. Meanwhile the obstacles faced in protecting women victims of domestic violence are the absence of implementing regulations related to protection orders, limited funds and the issuance of visum et repertum takes a long time, limited human resources such as the absence of psychologists, lack of maximum counseling services for victims, and the police's lack of understanding of the importance of protection orders for victims. Fourth, limited infrastructure and victims who were reluctantly placed in safe houses.
\end{abstract}

Keywords: Law Enforcement, Incursion, Land, Polda, South Sulawesi

\section{PENDAHULUAN}

Tanah mempunyai kedudukan dan merupakan hal yang sangat penting dalam kehidupan manusia. kehidupan manusia terus berkembang sejalan dengan perkembangan peradaban kehidupan manusia itu sendiri, menjadikan hubungan antar manusia semakin rumit mengenai tanah. Pertumbuhan penduduk, perpindahan penduduk, juga pesatnya pembangunan, menjadikan tanah yang luasnya tetap dan terbatas akan memicu konflik penguasaan hak atas tanah serta kondisi masyarakat yang semakin sadar dan peduli akan kepentingan/haknya, iklim keterbukaan yang digariskan pemerintah begitu pentingnya tanah bagi kehidupan manusia maupun dinamika pembangunan di samping membawa dampak positif meningkatnya harga tanah juga membawa dampak negatif yaitu timbulnya konflik pertanahan dengan berbagai macam modus operandi yang bersifat kompleks, multidimensi dan telah 
menjadi sorotan baik melalui media cetak maupun lewat media elektronik yang sering mengundang konflik dalam masyarakat yang pada hakikatnya, kasus pertanahan merupakan benturan kepentingan (conflict of interest) di bidang pertanahan antara siapa dengan siapa, sebagai contoh konkret antara perorangan dengan perorangan; perorangan dengan badan hukum; badan hukum dengan badan hukum dan lain sebagainya dimana masalah yang timbul dalam bidang pertanahan tidak lepas dari pelayanan administrasi.

Pelayanan administrasi dalam bidang pertanahan mempunyai peranan yang sangat penting bagi upaya mewujudkan jaminan kepastian hukum dan tertib hukum. adapun tertib hukum pertanahan dimaksudkan bahwa setiap bidang tanah penguasaan, pemilikan dan penggunaannya baik oleh pribadi maupun badan hukum mempunyai hubungan hukum yang sah menurut peraturan perundangundangan, dengan adanya hubungan hukum yang sah tersebut ditunjukkan antara lain oleh surat tanda hak atas tanah serta bukti kepemilikan yang sah yaitu sertifikat akan tetapi masih ada penguasaan, pemilikan dan penggunaan tanah oleh pribadi, badan hukum ataupun masyarakat yang melanggar ketentuan perundang-undangan agraria yang berlaku beserta peraturan pelaksanaannya, adanya penerbitan sertifikat yang tidak sesuai dengan data yuridis dan data fisik atas tanah oleh karenanya masalah sengketa hak atas tanah tersebut tidak dapat diabaikan begitu saja tanpa ditangani secara sungguh-sungguh. Masalah sengketa hak atas tanah dalam penanganannya tentu tidak dapat dilihat dari satu sudut pandang saja melainkan harus secara menyeluruh dan terpadu agar penyelesaiannya dapat digerakkan secara fungsional untuk mengambil peranan dalam menangani masalah pertanahan khususnya mengenai sengketa hak (laporan dugaan penyerobotan tanah ) atas tanah tersebut yang ditangani oleh tim Penyidik sesuai dengan tugas dan tanggung jawab yang diembannya sebagaimana tercantum dalam Undang-undang Nomor 2 Tahun 2002 tentang Kepolisian Negara Republik Indonesia.

Sesuai Undang-undang Nomor 5 Tahun 1960 Pasal 2 tentang Peraturan Dasar Pokok-pokok Agraria (selanjutnya disebut UUPA) yang menyatakan bahwa bumi, air dan ruang angkasa, termasuk kekayaan alam yang terkandung didalamnya itu pada tingkatan tertinggi dikuasai oleh Negara, sebagai organisasi kekuasaan seluruh rakyat. Hak menguasai dari Negara memberi wewenang kepada Negara antara lain untuk :

1. Mengatur dan menyelenggarakan peruntukan, penggunaan, persediaan dan pemeliharaan bumi, air dan ruang angkasa tersebut;

2. Menentukan dan mengatur hubungan-hubungan hukum antara orang-orang dengan bumi, air dan ruang angkasa.

3. Menentukan dan mengatur hubungan-hubungan hukum antara orang-orang dan perbuatan-perbuatan hukum yang mengenai bumi, air dan ruang angkasa tujuan undang-undang pokok agraria.

Analisis pelaku penyerobotan tanah dapat diartikan dengan perbuatan mengambil hak atau harta dengan sewenang-wenang atau dengan tidak mengindahkan hukum dan aturan, seperti menempati tanah atau rumah orang lain, yang bukan merupakan haknya (Tamal, at.al, 2019). Tindakan penyerobotan tanah secara tidak sah merupakan perbuatan yang melawan hukum, yang dapat digolongkan sebagai suatu tindak pidana dimana tujuan yang ingin di capai dalam pemidananan antara lain memperbaiki diri pelaku / tersangka itu sendiri, untuk membuat orang menjadi jera dalam melakukan kejahatan dan untuk membuat pelaku pidana tertentu menjadi tidak mampu untuk melakukan kejahatan-kejahatan yang lain yang pada hakikatnya untuk memulihkan Terganggunya keseimbangan antara kepentingan individu dan kepentingan umum agar terpelihara dan teciptanya situasi keamanan dan ketertiban sehingga semakin hari semakin berkurangnya dugaan terjadinya penyerobotan tanah yang terjadi diwilayah hukum Polda Sulsel serta pengetahuan masyarakat yang semakin berkembang dan memahami tentang ketentuan-ketentuan alas hak yang sah dimata hukum.

\section{METODE}

Jenis dan sumber data penelitian yang penulis gunakan terbagi dua antara lain:

1. Data Primer adalah data yang dikumpulkan dan diperoleh langsung dari hasil wawancara dengan para pihak-pihak yang mengklaim obyek tanah yang sengketa serta hasil observasi dan wawancara di Kantor Direktorat Reserse Kriminal Umum Polda Sulsel (sosiologis/empiris).

2. Data Sekunder adalah data yang mendukung data primer seperti peraturan perundang-undangan relevan, teks book, artikel, ilmiah jurnal dan hasil penelitian hukum serta makalah-makalah, buku dan literatur yang terkait atau berhubungan dengan materi penulisan.

Penelitian ini dilakukan di Polda Sulsel Subdit III Tahbang Ditreskrimum, Unit Pelayanan Perpustakaan Universitas Bosowa dan Pusat Informasi Fakultas Hukum Universitas Bosowa. Metode pengumpulan data primer dilakukan dengan cara wawancara kepada responden, informan maupun narasumber sedangkan data sekunder dalam penelitian ini dilakukan dengan cara melakukan studi pustaka terhadap peraturan peraturan perundang-undangan, buku-buku, dokumen dan arsip atau hasil pengumpulan data penelitian terdahulu yang berkaitan dengan obyek penelitian.

Adapun teknik pengumpulan data yang digunakan dalam penelitian adalah sebagai berikut :

1. Penelitian pustaka (library research) yaitu usaha pengumpulan data melalui bacaan, seperti buku literatur, karya ilmiah, majalah hukum, koran dan peraturan-peraturan perundang-undangan yang erat kaitannya dengan pokok pembahasan.

2. Penelitian lapangan (field research) yaitu usaha pengumpulan data secara langsung dilokasi penelitian dengan teknik :

a. Wawancara yaitu teknik pengumpulan data dengan jalan mengadakan tanya jawab mengenai hal-hal yang ada kaitannya dengan materi yang akan di bahas yakni proses penanganan perkara tindak pidana penyerobotan, pelaku penyerobotan, penyidik serta praktisi hukum

b. Observasi yaitu teknik pengumpulan data yang akan dilakukan dengan cara melakukan pengamatan langsung di Kantor Direktorat Reserse Kriminal Umum Polda Sulsel terhadap obyek yang di teliti.

Data yang di peroleh akan di analisis secara normatif kualitatif yaitu dengan cara menjabarkan dan menafsirkan data hasil penelitian yang di peroleh secara sistematis dengan 
didasarkan pada norma-norma hukum, khususnya dalam hukum acara pidana yang relevan dengan pokok-pokok masalah yang di teliti.

\section{HASIL DAN PEMBAHASAN}

\subsection{Data kasus tindak pidana penyerobotan tanah yang} terjadi di wilayah hukum Polda Sulsel

Pada wilayah tempat penulis melakukan penelitian yaitu Kantor Direktorat Reserse Kriminal Umum Polda Sulsel dalam hal Tim Penyidik dari Subdit III Tahbang, ditemukan berbagai kejahatan tindak pidana penyerobotan dan tindak pidana lain terkait pertanahan yang dilaporkan oleh masyarakat yang telah meresahkan masyarakat akibat sering kali melibatkan ormas / LSM / preman yang digunakan oleh pihak-pihak yang tidak bertanggung jawab untuk menduduki/ menempati atau bahkan menguasai obyek lokasi tanah dari pihak yang berhak berdasarkan alas hak yang sah sesuai dengan ketentuan yang berlaku (pasal 2 Undang-undang nomor 5 tahun 1960 tentang Peraturan Dasar Pokok-pokok Agraria) sehingga dalam penerapan hukum terjadi konkretisasi atau individualisasi peraturan hukum (das Sollen) yang bersifat umum dengan mengingatakan peristiwa konkrit tertentu (das Sein).

Dari hasil penelitian yang di lakukan oleh penulis di Kantor Direktorat Reserse Kriminal Umum Polda Sulsel, dari tahun 2015 sampai dengan tahun 2018 tidak terlepas dari laporan masyarakat perihal dugaan terjadinya tindak pidana penyerobotan tanah serta tindak pidana yang terkait penyerobotan tanah yang kemudian di tangani oleh Penyidik Direktorat Reserse Kriminal Umum Polda Sulsel, secara rinci dapat dilihat pada tabel berikut.

\section{Tabel 1}

Jumlah Laporan Dugaan Tindak Pidana Penyerobotan Tanah yang Terjadi di Wilayah Hukum Polda Sulsel Tahun 2015 2018

\begin{tabular}{cccc}
\hline Tahun & $\begin{array}{c}\text { Laporan dugaan } \\
\text { T.P penyerobotan }\end{array}$ & Selesai & $\begin{array}{c}\text { Tidak selesai/ } \\
\text { proses }\end{array}$ \\
\hline 2015 & 51 & 21 & 30 \\
2016 & 37 & 16 & 21 \\
2017 & 42 & 18 & 24 \\
2018 & 35 & 13 & 22 \\
\hline Jumlah & 165 & 68 & 97 \\
\hline
\end{tabular}

Sumber Data: Data sekunder yang diolah dari Polda Sulsel Tahun 2020

Berdasarkan Tabel 1 diatas, pada tahun 2015 terdapat 51 kasus yang di laporkan, dimana 21 (41\%) di antaranya telah selesai proses penanganannya sedangkan 30 (59\%) masih dalam tahap proses penyelidikan dan penyidikan, pada tahun 2016 terdapat 37 kasus yang di laporkan, dimana $16(43 \%)$ di antaranya telah selesai proses penanganannya sedangkan 21 (57\%) masih dalam tahap proses penyelidikan dan penyidikan, pada tahun 2017 terdapat 42 kasus yang di laporkan, dimana $18(43 \%)$ di antaranya telah selesai proses penanganannya sedangkan $24(57 \%)$ masih dalam tahap proses penyelidikan dan penyidikan, pada tahun 2018 terdapat 35 kasus yang di laporkan, dimana $13(37 \%)$ di antaranya telah selesai proses penanganannya sedangkan $22(63 \%)$ masih dalam tahap proses penyelidikan dan penyidikan, berdasarkan hasil wawancara penulis dengan IPDA AMRAN K, SH Penyidik Subdit III Tahbang Ditreskrimum Polda Sulsel (03 Januari 2020), diketahui bahwa : "hampir keseluruhan pelapor mengadukan dugaan tindak pidana penyerobotan tanah di SPKT Polda Sulsel juga melaporkan dugaan tindak pidana pengrusakan/secara bersama-sama maupun tindak pidana pemalsuan surat/autentik ataupun penipuan/penggelapan/ penggelapan hak dikarenakan menurut pelapor/korban bahwa cara melakukan penyerobotan tanah oleh pelaku adalah masuk dengan memaksa/melawan hak dengan merusak/membongkar maupun memindahkan tanda batas atau pagar maupun papan pengumuman diatas obyek tanah milik pelapor/korban sehingga mengalami kerugian sedangkan untuk pemalsuan surat/autentik atau menempatkan keterangan palsu di laporkan oleh pelapor/korban karna menurutnya bahwa pelaku melakukan penyerobotan tanah dengan menggunakan surat/autentik yang diduga palsu (rincik, girik, keterangan ipeda, bukti pembayaran pajak bumi dan bangunan serta bukti peralihan seperti akta jual beli, akta hibah maupun pengikatan jual beli bahkan berupa alas hak (sertifikat) untuk mengklaim obyek tanah yang di klaim milik pelapor / korban

Dengan jumlah perincian laporan dugaan tindak pidana penyerobotan tanah maupun laporan dugaan tindak pidana yang terkait dengan penyerobotan tanah, tim penyidik dari Ditreskrimum Polda Sulsel kemudian melakukan serangkaian kegiatan penyelidikan maupun penyidikan terhadap laporan tersebut sehingga diperoleh kepastian hukum terhadap laporan masyarakat apakah di tindak lanjuti ke proses penuntutan dalam hal ini kewenangan dari Jaksa Penuntut Umum hingga sampai ke Proses peradilan di Pengadilan Negeri atau sebaliknya tim penyidik tidak menemukan bahwa telah terjadi tindak pidana maupun tidak cukup bukti telah terjadi tindak pidana sehingga penanganan penyelidikan dan penyidikan di hentikan proses di tingkat Penyidik, data penyelesaian perkara dapat kita lihat seperti tabel dibawah.

Tabel 2

Jumlah Penyelesaian Perkara Tindak Pidana Penyerobotan Tanah yang Terjadi di Wilayah Hukum Polda Sulsel Tahun $2015-2018$

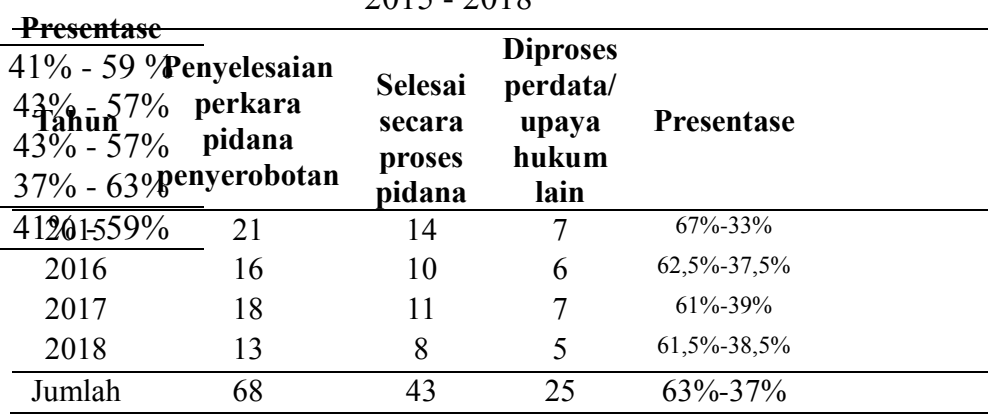

Sumber Data: Data sekunder yang diolah dari Polda Sulsel Tahun 2020

Data diatas dapat kita lihat bahwa proses penyelesaian perkara dari tahun 2015 hingga tahun 2018 tidak secara keseluruhan dapat diselesaikan dengan melalui proses pidana dalam hal ini serangkaian kegiatan penyelidikan maupun penyidikan akan tetapi dapat juga di selesaikan melalui proses jalur hukum gugatan perdata atau pun dihentikan karna laporan dugaan tindak pidana penyerobotan tersebut bukan tindak pidana / tidak di temukan bukti permulaan yang cukup sehingga proses penyelidikan dan penyidikannya di hentikan demi hukum akan tetapi tidak menutup upaya hukum yang lain yang dapat di lakukan oleh pengadu/pelapor dalam upaya mempertahankan / mengambilalih kembali obyek tanah tersebut, dari uraian ini dapat kita mengetahui peran besar dari Penyidik Subdit Tahbang Ditreskrimum Polda Sulsel untuk 
dapat menentukan selanjutnya arah penanganan laporan dugaan tindak pidana penyerobotan

\section{KESIMPULAN DAN SARAN}

Hasil penelitian dan pembahasan dapat disimpulkan bahwa terhadap proses penegakan hukum secara spesifik terhadap pelaku tindak pidana penyerobotan tanah maka kita membahas tentang " keadilan formal " (formal justice) yang dijalankan oleh penegak hukum (criminal justice system) yang kemudian melakukan proses hukum formal (proses hukum yang dilaksanakan oleh institusi negara di bidang hukum itu didasarkan pada hukum yang tertulis dan terkodifikasikan) dengan dikaitkan dengan cita-cita mendirikan Negara Kesatuan Republik Indonesia membentuk Negara Hukum (recht staat) dan bukan Negara Kekuasaan (macht staat). Penyidik Polri untuk melakukan tindakan Kepolisian baik preventif maupun represif dan dilanjutkan dengan proses hukum litigatif (law enforcement process) setelah adanya laporan/pengaduan akan tetapi dalam pelaksanaan masih ditemukan beberapa faktor yang mempengaruhi dalam proses penegakan hukum tersebut antara lain perundang-undangan (substansi hukum) dimana permasalahan yang timbul dari sengketa atas tanah semakin kompleks dan beragam baik motif pelaku maupun modus / cara yang digunakan oleh pelaku dalam melakukan dugaan tindak pidana penyerobotan tanah yang terjadi di wilayah hukum Polda Sulsel serta faktor penegak hukum (Penyidik Polri) yang harus cermat dan teliti dalam melakukan penegakan hukum secara profesional, modern, transparan dan akuntabel dengan tujuan memberikan perlindungan, pengayoman, dan pelayanan kepada masyarakat serta terbinanya ketenteraman masyarakat. Adapun terhadap faktor-faktor penyebab dugaan terjadinya tindak pidana penyerobotan tanah yang terjadi di wilayah hukum Polda Sulsel antara lain kurangnya kesadaran hukum masyarakat dan kurangnya pengetahuan hukum masyarakat serta faktor meningkatnya jumlah penduduk yang mengakibatkan meningkatnya kebutuhan ekonomi dan juga faktor individu atau kelompok itu sendiri yang melihat adanya kesempatan/peluang.

Untuk mengoptimalkan proses penegakan hukum terhadap pelaku penyerobotan tanah di Polda Sulsel diharapkan kepada Pihak Kepolisian Daerah Sulsel dalam hal ini Tim Penyidik untuk lebih mendalami dan cermat dalam melakukan proses penyelidikan maupun penyidikan terhadap dugaan tindak pidana penyerobotan tanah.

\section{DAFTAR PUSTAKA}

-, T., Pattenreng, H. A., \& Makkawaru, Z. (2019). Legal Analysis of the Implementation of Agreements For Palm Oil Products Between PT. Peaceful Jaya Lestari with Land Ownership in Kolaka District. Indonesian Journal of Legality of Law, 1(1), 43-45.

A. Zainal Abidin Farid, 1995, Hukum Pidana 1, Sinar grafika, Jakarta.

Ali, Achmad SH, MH, 2008, Menguak realitas hukum, Kencana ; Jakarta

Ali, Achmad SH, MH, 2015, teori hukum, Kencana, Jakarta

Andi Hamzah, 2006, Hukum Acara Pidana Indonesia, Sinar Grafika, jakarta.
Arief Barda Namawi, 2007, Masalah penegakan hukum dan kebijakan pidana dalam penangulangan kejahatan, Kencana, jakarta

Bambang Poernomo, 1993, Pola dasar teori penegakan hukum, Liberty, Yogyakarta

Boedi Harsono, 2005, Hukum Agraria Indonesia, Sejarah Pembentukan Undang-Undang Pokok Agraria, Isi dan Pelaksanaannya, cetakan kesepuluh, Djambatan, Jakarta

Ernest Utrech, 1962, hukum pidana 1, Universitas 1968, jakarta

Irawan Soerodjo,2003, Kepastian Hukum Hak Atas Tanah Di Indonesia, Arkola, Surabaya

Kep. Menkeh RI. Nomor M.01.PW.07.03 Tahun 1982 tentang Pedoman Pelaksanaan KUHAP

Kep. Menkeh RI. Nomor M.14.07.03 Tahun 1983 pedoman tambahan pelaksanaan KUHAP

Margono, Suyud, 2004, ADR (Alternative Dispute Resolution) dan Arbitrase: Proses Pelembagaan dan Aspek Hukum, Ghalia Indonesia Jakarta.

Moeljatno, 2008, Asas-asas Hukum Pidana, Rineka Cipta, Jakarta

P.A.F. Lamintang, 1997, Dasar-Dasar Hukum Pidana Di Indonesia, Sinar Grafika, Jakarta

Peraturan Kepala Kepolisian Negara Republik Indonesia Nomor 12 Tahun 2009 tentang pengawasan dan pengendalian penanganan perkara pidana di Lingkungan Kepolisian Negara Republik Indonesia (Berita Negara Republik Indonesia Tahun 2009 nomor 429)

Peraturan Kepala Kepolisian Negara Republik Indonesia Nomor 6 Tahun 2019 Tentang Penyidikan Tindak Pidana

Peraturan Pemerintah Republik Indonesia Nomor 24 Tahun 1997 tentang pendaftaran tanah

Perma Nomor 1 Tahun 2008 tanggal 31 Juli 2008 tentang prosedur mediasi di Pengadilan PP RI Nomor 27 Tahun 1983 tentang pelaksanaan Kitab Undang-undang Hukum Acara Pidana (Lembaran Negara Republik Indonesia Tahun 1981 Nomor 27, tambahan lembaran Negeran Nomor 3209)

Put. MK Nomor nomor : 21/PUU-XII/2014 tentang bukti permulaan, bukti yang cukup dan bukti yang cukup R. Soeroso, 2001, Pengantar Ilmu Hukum, Sinar Grafika, Jakarta

R. Soesilo, 1995, Kitab Undang-Undang Hukum Pidana (KUHP) Serta Komentar-Komentarnya Lengkap Pasal Demi Pasal, ctk. Ketujuh, Politeia, Bogor.

Romli Atmasasmita, 2001, Reformasi Hukum, Hak Asasi Manusia \& Penegakan Hukum, Mandar Maju, Bandung

Soerjono Soekanto, 2005, faktor-faktor yang mempengaruhi penegakan hukum, PT Raja Grafindo Perkara, Jakarta.

Undang-undang nomor 30 Tahun 1999 tentang Arbitrase dan alternatif penyelesaian sengketa.

Undang-Undang Nomor 51 PRP Tahun 1960 tentang Larangan Pemakaian Tanah Tanpa Izin Yang Berhak Atau Kuasanya.

Undang-undang Republik Indonesia Nomor 2 Tahun 2002 tentang Kepolisian Negara Republik Indonesia dan Undang-undang Republik Indonesia Nomor 3 Tahun 2002 tentang Pertahanan Negara

Undang-undang Republik Indonesia Nomor 5 Tahun 1960 tentang Undang-undang Pokok Agraria

Undang-undang Republik Indonesia Nomor 8 Tahun 1981 tentang Hukum Acara Pidana (lembaran Negara 
Republik Indonesia Tahun 1981 Nomor 76, tambahan lembaran Negeran Nomor 3209)

Urip Santoso, 2010, Pendaftaran dan Peralihan Hak atas Tanah, Kencana Prenada media group, Jakarta.

Warsito Hadi Utomo, 2005, Hukum Kepolisian di indonesia, Prestasi Indonesia, Jakarta 